VIII-1 | 2016

Dewey's Democracy and Education as a Source of and a Resource for European Educational Theory and Practice

\title{
William M. CURTIS, Defending Rorty: Pragmatism and
} Liberal Virtue

New York, NY, Cambridge University Press, 2015, 300 pages

\section{Wojciech Małecki}

\section{OpenEdition}

\section{Journals}

Electronic version

URL: http://journals.openedition.org/ejpap/476

DOI: 10.4000/ejpap.476

ISSN: 2036-4091

\section{Publisher}

Associazione Pragma

\section{Electronic reference}

Wojciech Małecki, «William M. cuRTIs, Defending Rorty: Pragmatism and Liberal Virtue », European Journal of Pragmatism and American Philosophy [Online], VIII-1 | 2016, Online since 20 July 2016, connection on 23 September 2020. URL : http://journals.openedition.org/ejpap/476 ; DOI : https://doi.org/10.4000/ ejpap.476

This text was automatically generated on 23 September 2020 .

\section{cc)}

Author retains copyright and grants the European Journal of Pragmatism and American Philosophy right of first publication with the work simultaneously licensed under a Creative Commons AttributionNonCommercial-NoDerivatives 4.0 International License. 


\title{
William M. CURTIS, Defending Rorty: Pragmatism and Liberal Virtue
}

\author{
New York, NY, Cambridge University Press, 2015, 300 pages
}

\author{
Wojciech Małecki
}

\section{REFERENCES}

William M. Curtis, Defending Rorty: Pragmatism and Liberal Virtue, New York, NY, Cambridge University Press, 2015, 300 pages

1 It is a historical truism that every thinker who made any impact on the field of philosophy also received his or her fair share of criticism, and it would therefore be surprising if Richard Rorty, at one time "the most quoted American philosopher," did not. ${ }^{1}$ But to merely say that he did would be an understatement. For Rorty happened to belong to the exclusive club of thinkers whose reception consists mostly of attacks. To be fair, throughout his career, he held academic positions at America's top institutions, published his work with top presses and in top journals, was a sought-after keynote speaker, an op-ed author for the New York Times, and even had a certain number of followers and sympathizers. But their number had always been small in comparison to the number of those following other philosophical superstars, including such bêtenoirs as Foucault or Derrida. No field was overtaken by his ideas, there was no army of Rortyans to support him, and most of the quotations that made him the most quoted American philosopher also made him the most criticized one. Practically all of his commentators recognized his originality, imagination, and erudition, and practically all of them also thought him completely wrong, independently of which philosophical quarter they represented.

2 As a philosopher, Rorty straddled the territory in between three philosophical traditions: pragmatism, continental, and analytic philosophy, but he was embraced in none and criticized by representatives of all three, including by heavy-hitters such as Hilary Putnam, Nancy Fraser, and John Searle. As a public intellectual, he was a vocal 
supporter of the ideal of social justice, which he shared with the contemporary Left, but he was at the same time fiercely critical of identity politics, a position usually associated with the right pole of the political spectrum. Partly as a result of this, he was again embraced neither by the Left, nor the Right, nor the Center, nor by any other significant part of the spectrum.

3 All this is said here, not in order to romanticize Rorty into a philosophical or political martyr or an "unhonored prophet of some social or intellectual revolution whose time has yet to come," but to stress the boldness of the project taken on by Curtis's in this new book, and to stress also the fact that attempts to defend Rorty such as his do not necessarily have to be insular projects that only committed Rortyans can profit from. Rorty was, after all, a widely-known thinker who was widely-criticized, often by other widely-known thinkers and in the context of some of the most-widely known debates of his time. In the right hands, a defense of Rorty could then become something of interest to anyone interested in the philosophical debates that rocked the philosophical world in the late-twentieth century, some of which in many ways have set the coordinates for the current ones. Curtis seizes that opportunity with very good results, focusing on the debate concerning whether liberalism can accommodate "the challenge of pluralism," $(9,12)$. His book is actually, by his own admission, an attempt to take a stand against those who think that it cannot and that it therefore has to go (ix). If Curtis makes so much of defending Rorty, this is mainly because he thinks Rorty's version of liberalism is best-suited to fend off the aforementioned criticisms - and the best version overall.

4 Consistent with that goal, Curtis begins his book by laying out in the introduction what the challenge of pluralism consists in and explaining why other attempts by liberal theorists to address it have proven ineffectual. The challenge is, roughly, that pace its founding fathers, rather than being an ethically and culturally neutral framework that springs from the dictates of universal reason and allows potentially all ways of life to peacefully coexist in society, liberalism is itself an ethically-charged, culturally specific way of life, and as such it is often incompatible with some of the ways of life which it is in principle supposed to help flourish and which are generally no less "reasonable" than liberalism itself. To argue, then, that contemporary societies should be liberal is to risk appearing "intolerant, and therefore oppressive, imperialistic, and ethnocentric" (21).

5 The most popular way to save liberalism from such accusations has been, quite predictably, to purge it as much as possible of anything culturally or ethically specific: to thin it out so as it could become as compatible as possible with all the known ways of human life. The results include conceptions such as political liberalism and modus vivendi liberalism. The problem with both, argues Curtis, is that they are unstable between a position in which their supposedly thinned-out liberal procedures work but only at the price of smuggling in some thick cultural or ethical content through the back door, and one where the process of purification is completed but only at the cost of making that content-free position no longer a version of liberalism.

Unhappy with a choice between hypocrisy and a de facto abandonment of liberalism, Curtis chooses to bite the bullet. He frankly admits that liberalism is a culturallyspecific way of life, and that there is no other way to follow it than to actually live it, something which demands developing a specific set of dispositions, habits, and attitudes, and cannot be achieved merely by abiding to a set of "abstract principles." 
The only honest and workable form of liberalism turns out to be, at least for Curtis, virtue liberalism - of the kind of proposed by Stephen Macedo and Rorty himself.

While there are many specific features of Rorty's brand of virtue liberalism that Curtis finds appealing, the one which stands out in light of the pluralist challenge is that while Rorty has no qualms about declaring his preferred liberal ethos superior to any other way of life, he does not try to argue that his preference is backed by universal, transcultural rationality. He abandons "the traditional philosophical quest for neutral foundations for liberalism, and [...] boldly admit[s] that liberalism is indeed 'ethnocentric': an idiosyncratic, parochial cultural development of Enlightenment Europe, and no less defensible for being that" (21). That Rorty is able to do so (to be a firm believer in liberalism while at the same time accepting its contingency), is made possible by his "anti-authoritarianism," a position he developed outside of political philosophy per se, as a result of his interventions in the philosophy of language and epistemology.

Chapter 1 cursorily surveys that work, discussing its roots in classical pragmatism, the work of Wittgenstein, Davidson, and Sellars as well its critical reception among Rorty's contemporaries (McDowell and Putnam) in order to provide some background for understanding what anti-authoritarianism amounts to. And what it amounts to is a recasting of Rorty's anti-representationalism where the rejection of the view that truth consists in correspondence to the way things really are is framed as "a protest against the idea that human beings must humble themselves before something non-human, whether the Will of God or the Intrinsic Nature of Reality." 3 According to Rorty, the epistemic imperative of justifying one's beliefs once and for all (whether in science, politics, morality, or in any other domain of human life) by checking them against "reality as it is in itself," is a mere expression of an atavistic "sado-masochistic" urge to kneel before a non-human authority. Anti-authoritarians, on the contrary, do not feel that urge, which is because they do not believe in such authorities. For them, justification is a "social game" whose "constraints are contingent and practice-based, as opposed to necessary and metaphysical" (53). The only epistemic authority they can imagine and recognize is the community of their "fellow-inquirers."

Once he has laid out how he understands the anti-authoritarian component of Rorty's anti-authoritarian liberalism, Curtis turns, in Chapter 2, to the liberalism part per se. What Rorty shares with most other liberals is his ideal of society as one where "discussion of public affairs will revolve around (1) how to balance the needs for peace, wealth, and freedom when conditions require that one of these goals be sacrificed to one of the others; and (2) how to equalize opportunities for self-creation and then leave people alone to use, or neglect, their opportunities," ${ }^{25}$ and what he shares in particular with virtue liberals, as Curtis quite convincingly shows, is his emphasis that that ideal cannot be achieved without the citizens of liberal society adopting a certain set of attitudes and dispositions. What Rorty adds to the typical catalogue of liberal virtues, and what at the same time connects his political philosophy to his interventions in epistemology and metaphilosophy, is what Curtis calls "the liberal civic virtue of irony," (89) and which is best described as internalized anti-authoritarianism.

Rorty's famed liberal utopia is, then, a society that (a) exemplifies the aforementioned ideal common to most liberals; and (b) whose citizens are, in addition, commonsensically anti-authoritarian. It is precisely this meta-virtue that allows Rorty's ideal citizens to both be committed to liberalism and to admit that that commitment is 
contingent, as contingent as any other political commitment for that matter. When confronted with somebody whose commitments conflict with their own, such liberals do not invoke any non-human authority that would allegedly stand on their side, providing them with a metaphysical seal of approval, nor do they a priori abstain from trying to convince their interlocutor to liberalism on the grounds that there is no noncontingent ground on which this can be done. Instead, they simply invite her to imagine what being a liberal might be, and to see if she likes it. Their civic virtue of irony provides them with "critical open-mindedness"; that is, "a sense of one's fallibility and finitude, which can nevertheless be combined with an ability to be steadfast in one's currently best-justified judgments." ${ }^{6}$

11 While in this and the preceding chapter of the book, Curtis does make some attempts to strike at Rorty's critics, he launches a concerted counterattack only in Chapters 3 to 5 , titled, respectively, "Critics: From Left to Right," "Rorty versus Taylor," and "Rorty, Religion, and Public Liberalism." Always fair and patient with his targets (and most of the time managing not to cross the fine line between fairness and pedantry), Curtis generally manages to get the better of them, pointing to the inaccuracies of their readings of Rorty as well as various problems with their own positions. He ends on a positive and applicatory note in Chapter 6, where, drawing on Rorty's own suggestion that science fiction is "the most [...] imaginative and most fruitful genre of long-term political deliberation," he provides a reading of Aldous Huxley's utopian novel Island as a more concrete illustration of a Rortyan utopia than Rorty himself ever penned.

12 It is beyond the scope of this review to assess whether Curtis's book will convince his fellow virtue-liberals to go down the Rortyan road, but there is no doubt that they should profit from reading it, as would anyone interested in the philosophy of liberalism. Most importantly, however, the book is a success as a work of Rorty scholarship, and on many levels. First, it could serve as a good introduction to Rorty's specific brand of liberalism for lay readers as Curtis does a fine job at clarifying Rorty's basic ideas and drilling through the crust of misinterpretations that have been sedimented on these ideas in secondary literature. But even those who have a good grasp of Rorty's basic ideas and who can seen through the misinterpretations themselves can profit from the book too, beginning with small things like Curtis's playful, yet in its specific sense accurate, parallel between Rorty and Thomas Aquinas (4) and ending with his novel idea of inscribing Rorty in the tradition of virtue liberalism. Curtis himself stresses that that gesture is his attempt at redescribing Rorty in Rorty's own sense of redescription (4), and I would add it is a successful one. ${ }^{8}$ It is successful because not only does it lead him to some original and striking insights about Rorty, but also because the redescription radiates, so to speak, to the areas of Rorty's work Curtis himself does not touch on.

13 To give you an example from my field, I have for years realized that one of the things that distinguish Rorty's literary theory and aesthetics from the work of his contemporaries is that he puts a strong emphasis on the psychological predispositions of readers of literature rather than on the methodologies of interpretation (to Rorty's mind, in order to be a good reader first of all you have to have a certain inclination toward texts). But thanks to Curtis's talk about Rorty's virtue liberalism and virtue epistemology (54), at some point in reading his book, I had a micro-epiphany, realizing that Rorty might be redescribed as a virtue aesthetician too. Suddenly, I began to see connections between various dots in Rorty's literary theory and aesthetics that I 
previously had never thought of, and some new dots began to emerge as well. Then, in a still wider perspective, I began to notice a network of lines crossing between Rorty's aesthetics and the other areas of his thought, all of which appeared to me to be connected in virtue of their emphasis on, well, virtue. Fresh as this impression is, and I cannot guarantee that, when the post-epiphanic dust settles down, the account of Rorty as a virtue aesthetician will stay with me for good. But a kind of ephiphany that was for certain: it allowed me to see what I have been working on for years in a new light, and see some novel vistas of inquiring into it. Judged in Rorty's own terms, this is precisely what redescriptions are for, and even if we put Rorty aside, such experiences are simply valuable in themselves for any specialist in any field.

Curtis's book possesses many other virtues, but it is not entirely free of vices, at least one of which is a function of a particular virtue. What I mean is that Defending Rorty is generally quite well-researched, referencing both Rorty's classics and quite obscure, smaller pieces, which makes certain omissions it contains more glaring than it would have been the case with a less informed study. Let me mention just two. It is rather baffling that Chapter 6, which reinterprets Huxley's utopian fiction Island as a concrete description of a Rortyan liberal utopia (one that Rorty's own work apparently lacks) does not even mention "Looking backwards from the Year 2096" - nothing less than Rorty's closest attempt at... describing this kind of liberal utopia in concrete terms, and at the same time Rorty's only attempt at political fiction, with a nod toward Edward Bellamy's famous socialist utopia Looking Backward: 2000-1887. ${ }^{10}$

Second, Defending Rorty never refers to the Rorty volume of the Library of the Living Philosophers, ${ }^{11}$ something which I mention here not out of mere pedantry, but because that collection contains some of Rorty's final, at least biographically, statements on his main ideas, including a few that are critical for Curtis's analyses. I believe, for example, that having spent so much time in his book discussing Rorty's notion of irony, Curtis should have at least mentioned Rorty's reply to J. B. Schneewind, included in the said volume, where Rorty openly disinherits his trademark character of "the liberal ironist," judging his portrayals of that figure in Contingency, Irony, and Solidarity, as "badly flawed" and "misguided." 12

But these are merely quibbles, and whatever other problems I might have with Curtis's book, my general judgment, which I would like to leave the reader with, is that it is perhaps the most defensible defense of Rorty's political philosophy ever written, and certainly one of the most refined, patient, comprehensive, and stimulating works on that subject available.

I would like to thank David Wall for reading the penultimate draft of this review.

\section{NOTES}

1. Eduardo Mendieta, (2005), "Introduction," in Take Care of Freedom and Truth Will Take Care of Itself: Interviews with Richard Rorty, Stanford, Stanford University Press, xii. 
2. Richard Rorty, (1998), Truth and Progress, Philosophical Papers, volume 3, Cambridge/New York, Cambridge University Press, 50.

3. Richard Rorty, (2006), "Pragmatism as Anti-Authoritarianism," in John R. Shook \& Joseph Margolis, (eds.), A Companion to Pragmatism, Blackwell Publishing Ltd, 257.

4. Richard Rorty, (1982), Consequences of Pragmatism: Essays 1972-1980, 1 edition, Minneapolis, Univ of Minnesota Press, 165.

5. Richard Rorty, (1989), Contingency, Irony, and Solidarity, Cambridge-New York, Cambridge University Press, 88, quoted in Curtis, 82.

6. (Ibid.: 96).

7. Richard Rorty, (2001), "Response to Matthew Festenstein," in Matthew Festenstein \& Simon Thompson (eds.), Richard Rorty: Critical Dialogues, 1 edition, Cambridge, UK, Malden, MA, Polity, 222.

8. For a detailed account of Rorty's conception of redescribing the work of a given philosopher as a hermeneutic strategy see my, "On a Man Who Died from Reading Too Much Heidegger, or Richard Rorty as a Reader," Contemporary Pragmatism, 11, 1 (2014), 115-29.

9. Richard Rorty, (1999), Philosophy and Social Hope, London, Penguin Books Limited, 243-51.

10. The America of the year 2096 depicted in Rorty's narrative definitely "reminds one in several respects of Rorty's liberal utopia as it is portrayed in his other works. Namely, a country in which communal life is organized around the notion of fraternity (an equivalent of Rorty's solidarity), and in which the primary source of moral instruction is not philosophical ethics, but 'Scripture and literature'- since fraternity is universally conceived of as a matter of sentiments ('an inclination of the heart, one that produces a sense of shame at having much when others have little'), and not of rational argumentation. 'Political discourse,' moreover, is devoid of overly theoretical divagations about principles, and reduced to finding practical measures that would 'prevent the re-emergence of hereditary castes - either racial or economic'." Wojciech Małecki, "'Nine chances out of ten that things will go to hell': Rorty on Orwell, Silko, and Narratives of the Dark Future," in Randy Auxier \& Krzysztof Skowroński (eds.), Richard Rorty and Beyond, Lexington Press, forthcoming; the quotations within the quotation are from Philosophy and Social Hope, 248-9.

11. Randall E. Auxier \& Lewis Edwin Hahn, (eds.), (2010), The Philosophy of Richard Rorty, Chicago and La Salle, Open Court.

12. Richard Rorty, "Reply to J. B. Scheewind," in Ibid., 506. As Rorty explains, "I conflated two quite different sorts of people: the unruffled pragmatist and the anguished existentialist adolescent. I made it sound as if you could not be an antifoundationalist and a romantic selfcreator without becoming a Sartrean, ever conscious of the abyss. But one can be both and remain, as far as philosophy goes, a placid Deweyan - someone who is nominalist and a historicist, but not much troubled by doubt either about philosophical doctrine or about her own moral or political outlook. It was a mistake to suggest (as I did at p. 87 of Contingency, Irony, and Solidarity) that all ironist intellectuals were afflicted with such doubts." (Ibid.) 


\section{AUTHORS}

\section{WOJCIECH MAtECKI}

University of Wrocław

wojciech.malecki[at]uwr.edu.pl 